\title{
European judicial training: promoting the development of standardised training materials and an interactive training methodology
}

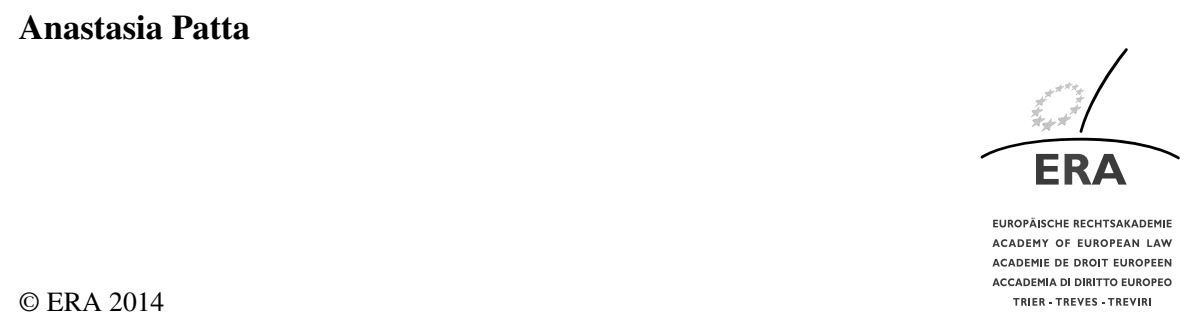

"Strengthening trust, mobility and growth within the Union" are the main challenges to be tackled, according to the Commission's new EU Justice Agenda for 2020, ${ }^{1}$ in order to pave the way for a fully functioning European area of justice. Although important steps in this direction were made through the introduction of new EU legislation based on mutual trust and recognition, thus building bridges between the different justice systems of the Member States, EU justice policy will enter a new dynamic period as of 1 December 2014. The end of the transitional phase set out in the Lisbon Treaty for the area of justice, as well as the concurrent end of the European Council's five-year Stockholm Programme ${ }^{2}$ and the following Commission Action Plan, ${ }^{3}$ was a unique opportunity to identify the existing challenges and to set the political priorities in order to overcome these challenges, and to make further progress. According to the Commission's Communication, "the focus of EU justice policy in the years to come should be on consolidating what has already been achieved, and,

\footnotetext{
${ }^{1}$ Communication from the Commission to the European Parliament, the Council, the European Economic and Social Committee and the Committee of the Regions of 11 March 2014-The EU Justice Agenda for 2020 - Strengthening Trust, Mobility and Growth within the Union (COM(2014) 144 final).

${ }^{2}$ European Council, The Stockholm Programme - an open and secure Europe serving and protecting citizens (2010/C 115/01).

${ }^{3}$ Communication from the Commission to the European Parliament, the Council, the European Economic and Social Committee and the Committee of the Regions of 20 April 2010-Delivering an area of freedom, security and justice for Europe's citizens-Action Plan Implementing the Stockholm Programme (COM(2010) 171 final).
}

A. Patta, Project Lawyer, Private Law (凶)

Academy of European Law (ERA), Trier, Germany

e-mail: apatta@era.int 
when necessary and appropriate, codifying EU law and practice and complementing the existing framework with new initiatives."

In the areas of civil and commercial law, a significant number of legislative instruments have been adopted by the European Union during the past fifteen years. Although codification could and should be considered, especially in the area of conflict of laws, and although complementary justice policy initiatives could also prove to be beneficial upon careful assessment, the main focus should lie on consolidation. As laid down in the Commission's Communication, "instruments agreed at EU level must be transposed by Member States, effectively implemented and used."

This can inter alia be ensured if national legal practitioners are in the position of identifying, interpreting, applying and enforcing EU law, relevant in a constantly growing number of cases affecting the daily lives of European citizens and businesses. For this reason, the Commission stresses once again the necessity of training legal practitioners in EU law and assisting them to become real "Union law legal professionals". Judges, lawyers, notaries and judicial staff should have access to initial and continuous training on the EU acquis and judicial cooperation at both national and EU level. That this is one of the main priorities is made clear by the fact that $35 \%$ of the 2014-2020 Justice Programme's overall budget will "support and promote high-quality European training projects for all justice professions and help share best practices on subjects such as curricula or interactive training methodology". ${ }^{4}$ This decision greatly supports the goal set of ensuring that half of all 700000 legal practitioners in the EU are trained in EU law or in the national law of another member state by $2020 .^{5}$

More than 130000 legal practitioners received training in EU law in 2011 and 2012, proving that the Commission's target is achievable. ERA, having been awarded not only operating but also action grants under several financial programmes over the last few years, is contributing to the achievement of this target. In order to do so in an innovative and value-added manner, ERA decided to adopt a very practical approach to European judicial training and proceed with the development of standardised training materials which will be reusable in future training activities.

Two projects covering the area of judicial cooperation in civil matters, currently being implemented by the Private Law Section of the Academy with the financial support of the Commission, are a good example of this approach: the project (1) on the development of tailor made and self-standing training modules ${ }^{6}$ and the project (2) on the development of training materials - case studies conceived in a way to be used in the context of interactive training seminars. ${ }^{7}$ Both projects involve and require several steps, from the conception and development of the training packages, as well

\footnotetext{
${ }^{4}$ See Annex of Regulation (EU) No 1382/2014 of the European Parliament and of the Council of 17 December 2013 establishing a Justice Programme for the period 2014 to 2020.

${ }^{5}$ Communication from the Commission to the European Parliament, the Council, the European Economic and Social Committee and the Committee of the Regions of 13 September 2011_Building trust in EUwide justice: a new dimension to European Judicial Training (COM(2011) 551 final).

${ }^{6}$ Framework service contract No JUST/2010/JCIV/PR/0016/A4_Development of tailor made training modules regarding European legislative instruments for cross-border cooperation in civil matters.

${ }^{7}$ Grant Agreement No JUST/2013/JCIV/AG/4686-Using EU Civil Justice Instruments: Development of training materials and organisation of test seminars.
} 
as the organisation and implementation of test seminars targeting different groups of legal practitioners around the EU, through to the dissemination of their results, thus ensuring their truly European dimension and sustainability.

In 2012, ERA received a grant to develop training modules in the area of EU family law for the first time. There are currently around 16 million international couples in the EU. It is inevitable when such families break up that family members often end up living in different countries, a situation that is fraught with difficulties from a family law point of view. These difficulties include, for example, knowing which courts have jurisdiction to hear a divorce application or a case on matters of parental responsibility, how a judgment will be recognised and enforced in another member state, the issue of enforcement of maintenance obligations abroad and how crossborder parental child abduction can be prevented. The main objective was to familiarise legal practitioners confronted with such cases involving cross-border elements with the EU acquis in family law. Two separate and independent training modules, namely on "Cross-border divorce and maintenance: jurisdiction and applicable law" and on "Parental responsibility in a cross-border context, including child abduction" were devised, offering an entire training package accessible by any party or institution interested in organising future training with a duration of 2.5 days in this area of law.

The aim set was to provide interactive training materials which would promote interrogative and participative learning methods and be easily reusable, which resulted in the development of materials addressed to both end users and training providers.

The "users' pack", which not only includes the traditional documentation with the related legislation and jurisprudence of the Court of Justice of the EU, is already partially distributed to end users in advance of the training in the form of an introductory e-learning course. Blended learning as a methodological tool ensures initial familiarisation with the scope and objectives of the training and a level playing field for all participants, while at the same time it constitutes a source for future reference, as it remains freely available after the completion of the training event. Although a significant part of the training relies on the provision of information on different legal instruments through face-to-face presentations, some practical experience in the particularities of cross-border family law cases, the procedures in place and the available tools, was deemed necessary. The "user's pack" is thus complemented by workshop exercises (case studies, IT-supported training sessions, role play) requiring the active contribution of the participants.

In order to guarantee a holistic approach to the area of law covered by the training modules, sections from each member state (except Denmark) have been added, complementing the EU acquis by presenting the specific legislative measures and procedures adopted and implemented at national level, including the relevant national jurisprudence and a general bibliography. This useful tool, integrated in the e-learning course, provides legal practitioners with all the necessary material for recognising and appreciating the interrelation and interaction between EU and national legislation in the area of family law.

In addition to the materials included in the "users' pack", training providers have access to the "trainer's manual" which specifies how to best navigate through the materials available and how these may be integrated in future workshops by providing 
information on its structure, content and methodology. Further to this, information on the organisational aspects of a training event, such as guidelines on how to identify possible trainers, select the participants or evaluate the training event, have been included.

Upon finalisation of the two training modules, various implementing workshops were organised in order to test, evaluate and update the developed materials. The workshops addressed different target groups (judicial trainers, judges, lawyers) and were carried out with the support of cooperation partners in various Member States and using diverse language regimes, thus allowing ERA to test the flexibility and adaptability of the materials in organising training events at a pan-European, regional or even national level. The positive feedback received from trainers and participants of those test workshops led the Commission to the decision to finance the translation of the training modules into more official languages of the EU and the organisation of a new series of workshops. By the end of 2014, the two training modules will be made freely available in six languages and approximately 380 legal practitioners from all corners of the EU will have received interactive and practical training on EU family law.

Regulation (EC) No 861/2017 establishing a European Small Claims Procedure (ESCP) has been applied in the EU (except in Denmark) since 1 January 2007. Its objective is to simplify and speed up litigation concerning small claims in cross-border cases and to reduce costs by offering an optional tool in addition to the existing possibilities under national laws. The ESCP facilitates access to justice and contributes to the implementation of the principle of mutual recognition of judgments in civil matters. However, lack of awareness of its existence among judges and other legal professionals, as well as shortcomings in its practical application, have been reported by consumers who have used this procedure in recent years. The development of a training module on the ESCP, with the aim of further raising awareness and guaranteeing its correct application, has been decided by the Commission. ${ }^{8}$ Following the successful example and structure of the training modules in the area of EU family law, ERA delivered the related training materials and initiated a series of implementing workshops at the beginning of 2014. By the end of 2014, the training module on the ESCP will be made available in English, French and German, and six workshops addressing both judicial trainers and end users will be organised.

Taking into account the very positive feedback received on the development of the training modules and the organisation of interactive and practice-oriented workshops, the Academy proposed implementing a new project on developing training materials in the area of cross-border cooperation in civil matters. At the beginning of 2014, this project was awarded a grant under the Commission's "Civil Justice" Programme and is currently being implemented in partnership with 16 judicial training bodies and bar associations as well as with the support of the European Judicial Training Network (EJTN). The aim of this project is to provide the framework and materials for training based on solving coherent practical case studies, thus requiring the active

\footnotetext{
${ }^{8}$ Specific contract No JUST/2012/JCIV/FW/0163/A4 implementing Framework service contract No JUST/2010/JCIV/PR/0016/A4.
} 
involvement of participating legal professionals and steering a continuous exchange of knowledge.

Three main topics with great practical relevance for EU legal practitioners have been identified for the purposes of the project, namely: (a) cross-border civil litigation, (b) European cross-border procedures and (c) conflict of laws. For each topic, three comprehensive and increasingly complex case studies will be developed by renowned external experts. These will consist of the case scenarios and suggested solutions, as well as the necessary background material and methodological advice for their implementation. The three case studies developed per topic will be conceived in a way to be used in the context of a seminar lasting 1.5 days and will be available in English, French and German from the beginning.

Once developed, the materials will be presented and discussed with national experts/judicial trainers, appointed by the project's partners, in the framework of a coordinating meeting spanning 2.5 days. The objectives of this meeting are to familiarise the national experts with the content of the materials, to conduct an initial evaluation of the developed case studies and to equip them with a framework for the organisation of future national training in the areas covered by the project.

The national experts will not be the only direct beneficiaries of the project, as the implementation of a series of 23 test seminars aimed at up to 30 participants each is made possible through the involvement of 16 partners from all over Europe. 20 national test seminars will be organised by the partners under the supervision of their national experts and with the support of ERA. These seminars will on the one hand allow for testing the materials with judges/lawyers at a purely national level, and on the other hand enrich the training materials by adding translations in eleven official EU languages. In order to ensure implementation of the training materials in a genuinely European context, ERA will organise three pan-European test seminars open to all legal professions. All in all, approximately 650 final recipients of EU judicial training from all over the EU will receive in-depth training in some of the main topics in the area of EU civil justice.

The real potential of a project aimed at the development of standardised training materials lies in the fact that it can have a long-term impact and be sustainable. The pan-European partnership of the project will ensure that information on the developed materials will be disseminated in various EU Member States from the very beginning. The partners involved will implement the materials through the organisation of national test seminars and also provide for a translation of (parts of) the materials into their national language, thus increasing the potential for further use in the context of future national, regional or pan-European training. Besides this, the training package will be offered to all interested stakeholders, institutions and networks active in the area of providing judicial training at both national and European level, thus enlarging the circle of beneficiaries and improving the sustainability of the project.

Lastly, accessibility of the training materials that ERA is developing, even upon the finalisation of the individual projects, is guaranteed through the specificallydeveloped project web pages, as well as through the ERA and EJTN websites. All finalised training materials in all available language versions are being uploaded and 
made freely accessible to all interested parties. ${ }^{9}$ The training modules developed in the area of judicial cooperation in civil matters will also be uploaded to the European e-justice portal, which is intended to serve as a future electronic one-stop-shop in the area of justice.

The projects presented, which are focused on the development of innovative and standardised training materials for the provision of practice-oriented European judicial training, should be regarded as initiatives towards furthering mutual trust and confidence among EU legal practitioners, and as a step forward in the development of a genuine European area of justice.

\footnotetext{
${ }^{9}$ More information on the materials available regarding the training modules in the area of judicial cooperation in civil matters can be found on the project's web page: https://www.era-comm.eu/EU_Civil_Justice_ Training_Modules. 